\title{
ENTRE BORGES E BENJAMIN: O ELOGIO DA TRADUÇÃO A PARTIR DA LITERATURA COMPARADA
}

\author{
BETWEEN BORGES AND BENJAMIN: \\ THE COMPLIMENT OF THE TRANSLATION FROM COMPARATIVE LITERATURE
}

Andrelino Ferreira dos Santos Filho*

\section{RESUMO}

O trabalho consiste na discussão levada a cabo pelas teorias críticas da Literatura Comparada acerca da relação entre centro e periferia, metrópole e colônia, global e local e, principalmente, a relação entre original e tradução. Trata-se de levantar a possibilidade de questionar a inferioridade hierárquica atribuída à figura da tradução como reação ao lugar subalterno destinado às culturas pós-colonialistas. Para tanto, nos serviremos dos pensamentos de Borges e de Benjamin.

PALAVRAS-CHAVE: Original. Tradução. Literatura. Identidade cultural.

\begin{abstract}
The paper consists in the discussion made by the critical theories of Comparative Literature on the relationship between center and periphery, metropolis and colony, global and local and, mainly, the relationship between original and translation. It is about raising the possibility of questioning the hierarchical inferiority attributed to the figure of translation as a reaction to the subaltern place destined to the post-colonial cultures. Therefore, we will rely on Borges and Benjamin's thoughts.
\end{abstract}

KEYWORDS: Original. Translation. Literature. Cultural Identity.

\section{INTRODUÇÃO}

A literatura comparada se alimentado enormemente de demandas oriundas de um cenário mundial portador das marcas de diversos fluxos. Segundo Arjun Appadurai (1999), a configuração cultural precisa rever a lógica binária sobre a qual se assenta a disjunção entre

\footnotetext{
* Doutorando em Filosofia FAFICH/UFMG. Doutor em Estudos Literários FALE/UFMG. Professor no Departamento de Filosofia da PUC Minas. E-mail: andrelinofilho@ yahoo.com.br.
} 
centro e periferia. Essa revisão deve compreender o dinamismo próprio do entrecruzamento de diversos panoramas como etnopanoramas, midiapanoramas, tecnopanoramas, finançopanoramas e ideopanoramas. Para Appadurai,

o sufixo 'panorama' também nos possibilita apontar para as formas fluidas e irregulares dessas paisagens, formas essas que caracterizam o capital internacional tão profundamente como elas caracterizam as modas internacionais do vestuário. (APPADURAI, 1999, p. 25).

O dinamismo de mundo - fruto desses fluxos - problematiza o caráter antagônico da relação entre local e universal. Pode-se dizer, que cada local é uma espécie de mônada que espelha a totalidade do mundo.

O câmbio cultural resultante das configurações e reconfigurações culturais oferece a matéria mais recente do capitalismo vigente - quer dizer, o capitalismo cultural. A cultura em fluxo pode ser reconhecida na figura da globalização cultural, e nela o risco de ofuscamento das diferenças sob o domínio instalado pela indústria cultural. Contudo, ao contrário da preocupação acerca do risco de ofuscamento das identidades culturais, o que pode ser observado é o aumento acentuado do reconhecimento das diferenças, desde que a cultura seja usada convenientemente, como acredita George Yúdice (2006).

A despeito da ênfase dada à questão por Yúdice, é preciso perguntar se o reconhecimento das diferenças pode efetivamente se alimentar da conquista da identidade cultural. Será que grupos minoritários têm encontrado na política o expediente a partir do qual sua reivindicação é reconhecida? O problema para um determinado grupo atingir o reconhecimento não é a falta de instrumentos políticos efetivos, mas a limitação dessa possibilidade à medida que as forças sociais são reconhecidamente forças no interior do tecido político ou, em outras palavras, do institucional.

O pleito no qual consiste a busca pelo reconhecimento da identidade cultural parece, pois, implica um círculo vicioso, pois as condições da reivindicação política se dão no interior do próprio cenário político. Quer dizer que o discurso da margem não é marginal, pois tem sido estabelecido, na esmagadora maioria das vezes, pressupondo um lugar institucional, qual seja a academia.

O pensamento ocidental que acreditara emancipar o ser humano - especialmente após o advento da ciência moderna inaugurada pela revolução copernicana - incorporou no século XX a denúncia de que a racionalidade instrumental não cumpriu o esperado em termos de modernidade. Nesse sentido, o ocaso do século XIX sugere fortemente - se não pode ser 
considerado também o ocaso da razão - pelo menos pode sugerir uma espécie de desconfiança da razão. Propostas messiânicas, nesse caso, tornaram-se simplesmente insuportáveis em face dos totalitarismos do século XX. E a referência às ruínas da razão não deve ser compreendida como uma defesa da pós-modernidade. Por outro lado, ignorá-la seria, no mínimo, improbidade acadêmica.

Em termos gerais, no mundo contemporâneo, o projeto racional moderno tem sido tomado como a ilusão da razão. Trata-se de uma constatação praticamente protocolar, na medida em que todas as formas de pensamento abrigadas pela pós-modernidade partem da mesma constatação, a saber, as ruínas da razão. E é neste contexto que emergiu o objeto da discussão que pretendemos levar a cabo no presente trabalho, o valor da tradução.

\section{O STATUS DA TRADUÇÃO}

Na medida em que a Literatura Comparada leva em consideração a discussão acerca da relação entre centro e periferia, metrópole e colônia, global e local, outra discussão precisa também ser considerada, a saber, a relação entre o original e a tradução.

A noção de tradução tem sido compreendida sob um lugar de inferioridade. Tal compreensão parece ser uma herança platônica, pois a tradução é, por vezes, vinculada ao lugar de cópia. É por isso que a preocupação de quem traduz e de quem recebe a tradução coincide na exigência de fidelidade ao original. Ou seja, quanto mais próxima do original, melhor a tradução ou a cópia. Trata-se de uma espécie de demiurgia que, no Sofista, de Platão, possui valor secundário.

A tarefa de discutir o status da tradução entre Borges e Benjamin tendo como horizonte a Literatura Comparada implica a desmistificação da hierarquia entre original e tradução. O principal elemento extraído dos textos de Borges é a máxima de que quanto mais tradução mais conhecimento se tem do original. Essa máxima não trata de afirmar apenas um critério quantitativo sem nenhum pudor, como se toda e qualquer tradução ou interpretação valesse. Para Borges o limite é a obra. Dentro dos limites da obra, pois, ele afirma que a riqueza das traduções pode comportar diversidade tanto quanto contradições, o que só potencializa o conhecimento acerca do original. De Walter Benjamin, a contribuição é a relação entre as noções de sobrevida e de tradução. O original se mostra em inúmeras faces engendrando a sobrevida da obra em suas traduções. É a aproximação entre tradução, 
imanência e verdade. Nesse sentido, a hierarquia para a qual o original recebe primado sobre a tradução é questionada. Traduzir é, pois, um ato imanente e gnosiológico.

Tomando de empréstimo as palavras de Borges, as quais dizem que o título é algo que o autor muito pensou, é preciso esclarecer o que significa estar entre Borges e Benjamin. Na esteira de Borges, o original é como um rascunho que torna-se cada vez mais polido, sem, no entanto, chegar a um formato final. Por isso, quanto mais traduções, maior o conhecimento do original. No caso de Benjamin, parece haver um fundo inatingível (o original) que reverbera através das traduções que ele demanda. Estar entre eles é sugerir que a verdade é um discurso que toca a coisa apenas tangencialmente. É uma escrita em torno, como se ainda houvesse um núcleo que a razão não pudesse atingir. Consiste em sugerir que a realidade é multifacetada e que não se esgota em nenhuma de suas faces. A rigor, quanto mais traduções, mais conhecimento se tem de algo.

Não se trata, no entanto, de assumir Borges no sentido de que só há tradução, como em Pierre Menard, autor de Quixote, pois parece impossível desconsiderar um fundo inatingível, uma sombra, aquilo do qual a tradução é demandada. É o que conduz a Benjamin em A tarefa do tradutor.

A hipótese que orienta estas considerações repousa, pois, no chão teórico tecido a partir de Borges e Benjamin. Se as traduções permitem a ampliação do conhecimento sobre o original (Borges) e este, por sua vez, sobrevive nas traduções (Benjamin), então a relação entre o original e a tradução é mediada por uma dimensão gnosiológica imanente. O original destina-se a ser conhecido através das traduções por ele demandadas.

As traduções, então, não são tomadas sob um lugar de inferioridade em relação ao original. Daí o elogio da tradução. O elogio consiste em atribuir valor à tradução, na medida em que está sendo tomada como a expressão multifacetada do original. Não se trata, portanto, de valorizar a tradução em função da proximidade do original. A compreensão da tradução sob o domínio da herança platônica - a tradução possui valor de cópia, portanto, um lugar subalterno em relação ao original - que exigiria de quem traduz e de quem recebe a tradução a fidelidade ao original deve ser senão recusada ou, pelo menos, problematizada tanto quanto a máxima de que quanto mais próxima do original melhor seria a tradução ou a cópia.

A máxima de que "quanto mais traduções mais conhecimento" articulada à aproximação entre sobrevida e tradução possibilita não apenas destinar um valor hermenêutico cada vez maior à tradução, bem como - e é o mais decisivo nestas 
considerações - ofuscar sua menoridade mantida através da submissão à heteronomia do original.

A noção de verdade intrinsecamente ligada à idéia de original é passível de ser revista. A questão da hierarquia entre o original e a tradução é que nos conduz a Borges. Tal hierarquia tem sugerido um lugar de inferioridade para a tradução, estabelecendo, assim, uma espécie de vínculo imanente entre original, essência e verdade. Nesse sentido, o ato de traduzir não é mais do que velar ou ofuscar o verdadeiro significado do original, consistindo sempre numa perda, o que gera, portanto, a necessidade de o tradutor se aproximar o mais possível do original. A rigor, a máxima que se infere daí é a de que quanto mais próximo do original for uma tradução, mais verdadeira é ela.

A tarefa de traduzir, de acordo com o espírito borgeano, é uma forma de engrandecer uma cultura, uma forma de dignificar uma língua. Tal máxima se funda em textos como As duas maneiras de traduzir (1926), As versões homéricas (1932), Os tradutores de mil e uma noites (1934), Pierre Menard, autor do Quixote. Entretanto, para não correr o risco configurar um pilar teórico tomando como base Borges enquanto escritor, nos apoiaremos na obra Esse Ofício do verso (2007), a qual reúne as seis conferências pronunciadas em Harvard no outono de 1967. Trata-se de um conjunto de textos teóricos que sustentam a teoria da tradução como rascunho, bem como a articulação com a noção de sobrevida de Walter Benjamin.

Do primeiro texto, interessa-nos a distinção entre as maneiras clássica e romântica de traduzir. A tradução clássica caracteriza-se pelo primado do texto. Significa que a psicologia e a biografia do autor não são relevantes para o estabelecimento da inteligibilidade do texto. Por outro lado, o texto não é tomado como uma construção acabada, como um monumento disponível para ser contemplado. Pois seria o mesmo que admiti-lo como uma figura hermética, cuja compreensão encontraria suas condições de possibilidade na intencionalidade do autor.

A opção de Borges, de acordo com Pastormerlo (2009), implica tomar textos como rascunhos. Enquanto rascunhos os textos sempre comportam a possibilidade de correções, ampliando seu horizonte de significação à medida que uma nova tradução é realizada. Tratase de uma escrita em torno, gerando uma riqueza maior do que o texto "original". Contudo, importa ressaltar, a escrita em torno não supõe uma hierarquia para a qual a última tradução é a mais verdadeira porque conteria todas as outras. Não parece haver hierarquização, pois o original é um rascunho que abriga infinitas ressalvas, infinitas traduções, como o círculo possui infinitos lados. O ideal romântico de tradução é recusado, pois ao tradutor não se 
impõe a exigência da fidelidade literal, até porque o câmbio de uma língua a outra impediria a correspondência entre as palavras. Entre o tradutor e a tradução não há a mediação do original, entendida no sentido de portador da verdade.

Em As versões homéricas, Borges valoriza a maneira clássica, combatendo mais uma vez o status especial atribuído ao original:

\begin{abstract}
A superstição da inferioridade das traduções - amoedada no consabido adágio italiano - procede de uma distraída experiência. Não há um bom texto que não pareça invariável e definitivo se o praticarmos um número suficiente de vezes. Hume identificou a idéia habitual de causalidade com a sucessão. Assim, um bom filme, visto uma segunda vez, parece ainda melhor; tendemos a considerar necessidade o que não passa de repetição. Com os livros famosos, a primeira vez já é segunda, posto que já os abordamos sabendo-os. A precavida e corriqueira frase reler os clássicos se reveste de inocente veracidade (BORGES, 1999, p. 255-256).
\end{abstract}

Nesse sentido, emerge uma noção de tradução posta como incansável labor em função das infinitas possibilidades de leituras. A tradução desvela a obscuridade que o texto original preserva:

\begin{abstract}
Nenhum problema tão substancial com as letras e seu modesto mistério como o que propõe uma tradução. Um esquecimento animado pela vaidade, o temor de confessar processos mentais que adivinhamos perigosamente comuns, o esforço para manter intacta e central uma reserva incalculável de sombra, velam as tais escrituras diretas. A tradução, por sua vez, parece destinada a ilustrar a discussão estética. O modelo proposto à sua imitação é um texto visível, não um labirinto inestimável de projetos pretéritos ou a acatada tentação momentânea de uma facilidade. Bertrand Russell define um objeto externo como um sistema circular, irradiante, de impressões possíveis; pode-se dizer o mesmo de um texto, em face das repercussões incalculáveis do verbal. Um parcial e precioso documento das vicissitudes que sofre permanece em suas traduções. (BORGES, 1999, p. 255-256).
\end{abstract}

A tradução abriga, assim, um princípio gnosiológico, já que à quantidade de traduções corresponde o grau de desvelamento das escrituras diretas. Tradução não é, pois, traição. Trata-se, antes, de um expediente que ilumina o original à medida que o desdobra. É um instrumento musical que transforma a cifra em acorde.

Embora não seja possível afirmar a existência de uma teoria da tradução em Borges, não se pode negar, pelo menos nos textos até agora referidos, uma espécie de elogio da tradução. É como se o original solicitasse tradução, inúmeras traduções, a fim de que o caráter de rascunho receba polimento cada vez maior a cada tradução realizada. Nesse sentido, diz Borges (1999, P. 256): “[...] a Odisseia, graças a meu oportuno desconhecimento do grego, é uma biblioteca internacional de obras em prosa e verso, desde os versos de rimas 
emparelhadas de Chapman até a Authorized version de Andrew Lang ou o drama clássico francês de Bérard ou a saga vigorosa de Morris ou o irônico romance burguês de Samuel Butler".

No mesmo contexto, Borges justifica sua preferência pelos ingleses, sem, no entanto, atribuir qualquer mérito à língua inglesa. A demanda por tradução que a Odisseia comporta se deve à circunstância "que deve ser exclusiva de Homero: a dificuldade categórica de saber o que pertence ao poeta e o que pertence à linguagem. A essa dificuldade feliz devemos a possibilidade de tantas versões, todas sinceras, genuínas e divergentes" (1999, P. 256).

A peculiaridade de Homero consiste no emprego de adjetivos, os quais "são expressões que recorrem, comovedoramente, a destempo" (1999, P. 256). Daí a dificuldade de realização de um trabalho filológico que pudesse estabelecer a tradução merecedora do título de canônica. É o que ocorre com trecho extraído do livro XI da Odisseia, o qual apresenta os fatos comunicados por Ulisses ao espectro de Aquiles. Borges cita nada menos que seis traduções do referido trecho, ressaltando no final que nenhuma delas merece o podium da verdade, embora todas sejam verdadeiras.

\begin{abstract}
Qual dessas muitas traduções é fiel? Talvez queira saber meu leitor. Repito que nenhuma, ou que todas. Se a fidelidade deve ser prestada à imaginação de Homero, aos irrecuperáveis homens e dias que ele imaginou, nenhuma pode sê-lo para nós; todas, para um grego do século $\mathrm{X}$. Se aos propósitos que ele teve, qualquer uma das muitas que transcrevi, salvo as literais, que extraem toda sua virtude do contraste com hábitos presentes. (BORGES, 1999, p. 256)
\end{abstract}

$\mathrm{Na}$ terceira conferência em Harvard Borges sustenta teoricamente As versões homéricas, cuja expressão maior se encontra na afirmação de que é possível dizer que, por muito tempo, histórias sobre Tróia, Ulisses, Jesus - têm admitem a possibilidade e/ou necessidade de serem contado e recontado muitas e muitas vezes. Elas foram musicadas, foram pintadas e mesmo que tenham narradas inúmeras vezes, as histórias continuam ali, ilimitadas.

A despeito da especificidade de Homero no que tange ao fomento de traduções, o mesmo raciocínio se aplica ao próprio texto borgeano. É o que ele afirma na entrevista que concedeu a Olga Pinasco (1981). Depois de observar que não cria que seus escritos merecessem atenção especial, afirma que o tradutor conhece seus textos melhor do que ele. "É que ele conhece o texto melhor que eu, que só o escrevi uma vez [...] e não há que se ater a esse jogo de palavras: traduttore-traditore". Mais uma vez, Borges ressalta o texto original como rascunho que demanda traduções, na medida em que se desdobra nelas. 
Em Los traductores de las mil y uma noches, Borges, segundo Cesco (2009), sugere, aproximando-se de Walter Benjamin em A tarefa do tradutor, que a tradução é uma forma de leitura. Diz a autora, na sequência:

\begin{abstract}
De acordo com Borges, cada tradutor de Las mil y una noches dá conta da particular concepção da literatura que domina na sua língua. A de Antoine Galland estava direcionada aos franceses do século XVIII, isto é, aos racionais leitores de Racine e Corneille. A de Eduard Lane, primeira versão inglesa, é puritana, 'centro de La lectura sin alarmas y de la recatada conversación'. A de Richard Francis Burton não esconde nenhum detalhe erótico. A de J. C. Mardrus não tem dúvida em aumentar, até inventar, 'el color oriental' indispensável ao público do novo mundo, espectador extasiado dos 'ballets rusos' de Diáguilev. As melhores traduções, opina Borges, não são as que restabelecem o significado ou as palavras do original, mas as que estão melhor escritas. As mais agradáveis de ler. (CESCO, 2009, p. 86-87)
\end{abstract}

A sugestão borgeana que podemos inferir do trecho acima é que o tradutor é um leitor privilegiado, na medida em que traduz para um determinado horizonte de expectativa e, ao fazê-lo, torna-se autor. Não quer dizer, no entanto, que o tradutor-autor possa se revestir de tamanha arbitrariedade que prescinda de qualquer limite na elaboração de sua versão, pois Borges procura, simultaneamente, valorizar todas as traduções, e acreditar que todas são verdadeiras. ${ }^{1}$

O limite imposto pela obra não significa que a tradução tenha de obedecer ao critério da literalidade. A tradução literal, segundo Borges, tem origem nas traduções da Bíblia: "Se pensamos no Espírito Santo, se pensamos na infinita inteligência de Deus empreendendo uma tarefa literária, não nos é permitido pensar em nenhum elemento casual - em nenhum elemento fortuito - em sua obra. Não - se Deus escreve um livro, se Deus se digna à literatura, então cada palavra, cada letra, como dizem os cabalistas, há de ter o seu propósito. E pode ser blasfêmia se intrometer no texto escrito por uma inteligência infinita, eterna" (BORGES, 1999, p. 78). Ainda que assim fosse, o tradutor, porque escreve para uma época distinta da destinação dada pelo autor, torna-se um novo autor.

Em Pierre Menard autor do Quixote, Borges reforça a designação de autor para o tradutor. É o que se passa no cotejo entre o Quixote de Cervantes e o Quixote de Menard.

\footnotetext{
${ }^{1}$ Acrescenta ainda Cesco (2009, p. 92) no mesmo trecho: "Voltando a entrevista que teve com Sábato, em certo momento os dois comentam sobre as traduções de alguns títulos de livros. Sábato discorre sobre a má tradução do título do livro de Saint-Éxupéry, Terre des Homes, que aparece traduzido como Tierra de Hombres, como se fosse 'Terra de Machos', 'quando na verdade quer significar - e diz isso claramente - Terra dos Homens, a terra desses pobres-diabos que vivem neste planeta. Não só o tradutor não sabia francês, como não entendeu nada de Saint-Éxupéry e de sua obra inteira...'. Borges concorda com Sábato e acrescenta: 'Claro, altera exatamente o título, que é onde mais trabalhou o autor. Quando escolheu um, é porque pensou muito nele. Ninguém, nem o tradutor, deve sentir-se no direito de mudá-lo".
} 
Constitui uma revelação cotejar o Dom Quixote de Menard com o de Cervantes. Este, por exemplo, escreveu (Dom Quixote, primeira parte, nono capítulo):

...a verdade, cuja mãe é a história, êmula do tempo, depósito das ações, testemunha do passado, exemplo e aviso do presente, advertência do futuro.

Redigida no século XVII, redigida pelo 'engenho leigo' Cervantes, essa enumeração é mero elogio retórico da história. Menard, em compensação, escreve:

... a verdade, cuja mãe é a história, êmula do tempo, depósito das ações, testemunha do passado, exemplo e aviso do presente, advertência do futuro. (BORGES, 1999, p. 492).

A fidelidade textual não pode ser tomada como uma defesa da forma romântica de traduzir. Ao contrário, o texto parece ser posto como uma máscara, sob a qual inúmeros autores podem se abrigar à medida que se apresentam como tradutores.

A tradução-clone sugere que a questão principal é singularidade da tradução em relação ao destinatário. Traduzir é, assim, atualizar uma obra, ainda que não implique acréscimos, decréscimos ou quaisquer modificações. Segundo Campos (2009, P. 90), “o conto de Pierre Menard parece ter o desejo de tocar em dois extremos, a questão da intenção e a questão da recepção do fenômeno literário. Trata-se aqui, por estranho que pareça, não do texto, mas de seus extremos. Trata-se do emissor e do receptor. Trata-se da criação de um personagem que é inventado por todo texto: o autor; e de outro personagem desejado por todo texto: o leitor".

A tradução, portanto, não é apenas uma forma de ampliar o conhecimento sobre o original. Ela é, antes, a sobrevida da obra, expressão que nos conduz a Walter Benjamin.

\section{TRADUÇÃO E SOBREVIDA DA OBRA}

Segundo Benjamin, a linearidade causal, ou a idéia de progresso, ancora-se numa compreensão problemática da noção de tempo. A problematização levada a cabo pelo filósofo em Magia e Técnica, Arte e Política (1994, p. 229) pode ser traduzida de forma paradigmática no seguinte trecho: "A idéia de um progresso da humanidade na história é inseparável da idéia de sua marcha no interior de um tempo vazio e homogêneo. A crítica da idéia de progresso tem como pressuposto a crítica da idéia dessa marcha".

Nesse sentido, a história é o próprio tempo vazio e homogêneo. A tarefa do historiador não é apenas estabelecer conexões como se os fatos permitissem por si mesmos a conexão que formaria um continnum, o que exigiria dele um olhar transcendental. Ele está inserido na imanência do processo histórico, o que recusa o telos da história e, de um só golpe, assume o futuro como contingência. 
O que interessa não é a especificidade do tratamento dado ao evento, e sim o modo como tal evento é inserido na temporalidade constituída por aquele continnum. Entretanto, não é diretamente a pergunta do filósofo que aqui interessa, mas a concepção de tempo que tal pergunta supõe. Em outras palavras, importa o conceito de temporalidade em Benjamin e o uso que faremos dele na nossa empresa.

A primeira consideração nesse sentido é a distinção entre origem (Ursprung) e gênese (Entstehung). Origem é a singularidade que traduz o encontro do universal (a idéia) com a particularidade dos fenômenos. Trata-se de um toque tangencial, cuja compreensão plena está embargada pela infinita distância entre o original e a tradução.

O hiato entre o original e a tradução explode o continnum da história de tal maneira que todo discurso historiográfico não é mais do que tradução.

Traduzir é um exercício permanente, um esforço que não pode se esgotar nele mesmo. A tradução é portadora ou, mais precisamente, manifesto da condição babélica originária, para a qual a comunicação não deve ser levada em consideração. Por isso, se existe algum telos $\mathrm{n} A$ tarefa do tradutor, ele não é certamente a transmissão de uma mensagem.

A forma pela qual o ensaio de Walter Benjamin A tarefa do tradutor foi traduzido no Brasil reverbera inconfundivelmente o traço babélico. ${ }^{2} \mathrm{O}$ babelismo, ou a "constelação babélica", como ressalta o Professor Karlheinz Barck, parece ser uma experimentação com o próprio ensaio de Benjamin, na medida em que o tradutor foi um sujeito coletivo constituído na confluência de pelo menos quatro diferentes línguas.

$\mathrm{Na}$ apresentação que abre a tradução brasileira é possível constatar muitos dos pressupostos que governam o ensaio. Expressões como "intenção da língua para a qual se traduz o texto", "original", e "tonalidade afetiva", traduzem o núcleo semântico da noção de sobrevida, tão caro a Benjamin. Tal noção, além de ser o ancoradouro no qual se aporta o trabalho de traduzir, encampa outras especificidades que - embora não seja a nossa pretensão explicitar exaustivamente aqui, vale dizer - permitem pensar a relação com a tradição. Nesse sentido, é de capital importância tomar a noção de língua pura para fazer emergir minimamente uma noção de tempo atrelada ao modo judaico de escrita, o que explicita, no fundo, a distinção entre origem e gênese, bem como realça um metafisicismo remanescente.

\footnotetext{
${ }^{2}$ A tarefa do tradutor foi traduzido para o português durante o seminário conduzido por Karlheins Barck, no primeiro semestre de 1992, na UERJ, como trabalho final. A experiência babélica que marcou essa atividade Barck propôs uma tradução coletiva - foi tão impressionante que não poderia ter sido mais bem descrita como a Apresentação do texto final.
} 
É no mínimo curioso - para não dizer problemático ou, mesmo, contraditório - ler metafisicamente A tarefa do tradutor para salvaguardar outra possibilidade de relação com o cânone, na medida em que o que funda e garante o primado da tradição ocidental é, de alguma maneira, um essencialismo tipicamente metafísico. Em A tarefa do tradutor Benjamin, intencionalmente, oferece um estatuto metafísico àquilo que em si é incognoscível e, simultaneamente, condição de toda inteligibilidade, sem se reduzir, no entanto, ao conceptualismo que consolida a especulação racional. Mais do que isso, trata-se de justificar esse domínio metafísico mediante a presença judaica e os pressupostos teológicos daí advindos.

No primeiro parágrafo de A tarefa do tradutor Benjamin recusa de forma contundente o telos que deveria - pelos menos é o que pareceria mais intuitivo - mediar a relação entre autor e receptor, qual seja, a comunicação. Segundo o filósofo, "nenhum poema é feito para o leitor; nenhum quadro, para o espectador; nenhuma sinfonia, para a audiência” (1994, p. 5). Nesse sentido, pode-se inferir que o que está em jogo aqui é a negação da recepção enquanto categoria gnosiológica. Ou seja, a especificidade de uma obra não se encerra naquilo que o receptor acredita compreender dela.

O estranhamento de que é passível tal propositura pode, no entanto, ser minimizado se levarmos em consideração que em A tarefa do tradutor existem indícios do chamado "paradigma estético"3, instância de mediação na passagem entre o período metafísico e o político-marxista. Esses sinais tratam da recorrência à arte. Mas o que significa isso? Significa a possibilidade de inferirmos daqui um essencialismo de orientação platônica que dá ao original inteligibilidade a priori, prescindindo, pois, de sua recepção. Ora, somente a noção de arte pode comportar tal prerrogativa, na medida em que nela a totalidade se manifesta no singular mediante movimento imanente. O todo - trata-se de uma efetividade, e não de mero universal abstrato - revelando-se no particular, isto é, universal concreto ou singularidade, traduz o modo de ser da arte, sua apresentação em cada obra particular. Assim, o todo encontra sua efetividade em suas partes, pois, antes de qualquer determinação, equivaleria ao nada; isto é, não seria mais do que uma generalidade.

\footnotetext{
${ }^{3}$ Conforme Francisco Machado ressalta acerca de Origem do drama barroco alemão, "se observarmos as reflexões epistemo-críticas de Benjamin, podemos identificar uma crescente secularização no seu uso da linguagem. Nesse sentido, o livro sobre o drama barroco alemão representa também uma mudança. A tentativa de expressar seus pensamentos através de uma terminologia estético-filosófica ao invés de teológica é, por exemplo, visível comparando-se a primeira versão do 'Prefácio', publicada postumamente, com a versão final. No próprio processo de elaboração do 'Prefácio' ocorre, portanto, uma tensão entre os pensamentos metafísicoteológicos e os advindos de uma abordagem estética”. Imanência e história: a crítica do conhecimento em Walter Benjamin. p. 21.
} 
O sentido - leia-se inteligibilidade - do ser está no seu devir. Ao caráter sintético que engendra a isonomia "quanto mais transcendência mais imanência" acrescenta-se "mais inteligibilidade". É assim que o esquema tríplice autor-mensagem-receptor é rompido, uma extrinsicidade suprassumida na imanência do ser.

Excluir a comunicação do finalismo que liga autor e receptor parece recusar o primado de um sobre o outro. Não há mais transcendência. E, nesse sentido, nada o demonstra melhor do que a figura da arte. A imanência, pois, que é própria da arte, desvela sua essência na singularidade de cada produção artística. De fato, esse movimento não visa a comunicar algo; antes, pressupõe na lei interna que o constitui sua própria inteligibilidade, bem como da tradução dessa inteligibilidade em discurso.

A independência da recepção exige que a compreensão se dê na relação imanente entre o todo e suas partes. Tal relação faz com que a obra de arte seja irredutível a categorias gnosiológicas extrínsecas, como "espírito de época" e "visão de mundo". Por outro lado, essa irredutibilidade garante à obra, por mais contemporânea de seu contexto que ela seja, estar sempre aberta à posteridade.

Permanecer no ser, como é próprio da obra que não se esgota nos limites de um contexto histórico, é a capacidade intrínseca que traduz a idéia de sobrevida. No caso da arte, o todo comparece com toda a sua plenitude nos seus modos de ser. A história, vale ressaltar, não é apenas cenário, mas a historicização do ser. Portanto, segundo Benjamin (1999, p. 8-9),

\footnotetext{
é a partir da história, não da natureza, muito menos de uma natureza tão instável quanto à sensação e a alma, que é preciso circunscrever o domínio da vida. Surge, assim, para o filósofo, a tarefa de compreender toda vida natural a partir desta vida mais extensa: a da história. [...] Todas as manifestações da vida, bem como sua própria meta, têm por fim não a vida, mas sim a expressão de sua essência, a apresentação (Darstellung) de seu significado.
}

A vida, isto é, a sobrevida, se remete ao ser e este, por seu turno, se apresenta como linguagem, porque é índice de sua própria inteligibilidade e discursividade. Nesse sentido, as línguas circunscritas historicamente são modos de ser dessa linguagem. Parece possível inferir com Benjamin que "a tradução tem por fim exprimir a relação mais íntima entre as línguas". (1994, p. 9).

A tradução, pois, deve abandonar qualquer pretensão à comunicação, porque, no fundo, toda comunicação possui um caráter mimético. Ora, a mímesis pressupõe uma fixidez que seria a morte do ser, já que ele é devir, provando-se, desse modo, que não seria possível tradução alguma se ela pretendesse concorrer como o original. O que a tradução faz é 
atualizar a afinidade das línguas, o que nada tem a ver com a semelhança entre elas. Entretanto, a afinidade compreende a capacidade de expressão, cuja lei imanente tem sempre no horizonte o que Benjamin denomina "língua pura". As línguas empíricas são, pois, modos de ser dessa língua originária. ${ }^{4}$

A boa tradução deve, portanto, apresentar o referente a partir daquilo que lhe é mais intrínseco, isto é, a intenção de significar. Por isso, diz Benjamin que

[...] toda afinidade meta-histórica repousa muito mais no fato que, em cada uma delas, tomada como um todo, algo é significado, que sendo o mesmo não pode, entretanto, ser alcançado por nenhuma delas isoladamente, mas apenas pelo todo de suas intenções reciprocamente complementares: a língua pura, com efeito, enquanto todos os elementos singulares, as palavras, as frases, as correlações de línguas estrangeiras se excluem, essas línguas se completam em suas próprias intenções. Para apreender exatamente esta lei, uma das fundamentais da filosofia da linguagem, é necessário distinguir, na intenção, o-que-se-significa (das Gemeine) do modo de significá-lo (die Art des Meinens). (BENJAMIM, 1994, p. 11).

A noção de língua pura parece indicar o logos hebraico como fundo. Trata-se de um núcleo que a tradução toca apenas tangencialmente. Esse núcleo é, mesmo que pareça contraditório, o intraduzível que demanda tradução, e isso infinitas vezes. É esse intraduzível que, pelo menos assim quer nos parecer, conduz à palavra (dabhar) hebraica, uma inteligibilidade velada e irredutível à representação, e que por isso não encerra apenas conhecimento ou comunicação no seu escopo. Ou seja, o que funda o original em A tarefa do tradutor é um sopro de vida, aquilo que possibilita a sobrevida. A vida originária, condição de possibilidade da vida nas suas determinações, permite ser tocada a cada vez na singularidade da tangente. A tradução é, neste sentido, um ponto tangencial.

Mas o que garante o estatuto do original é um valor metafísico. Independente da recepção, o ser, fundante do original, desdobra-se historicamente, o que não significa historicismo. O que faz de uma obra ser o original - o que está em jogo não é uma genealogia no sentido de procurar o momento historicamente determinado em que surge a obra - é o fato de ela demandar tradução, ainda que não haja um receptor.

A sugestão é que exista em Benjamin uma forma nuançada da escrita judaica. Basta lembrar que a tradição judaica é constituída pela Torah (a lei propriamente dita) e pelo Talmud (uma espécie de jurisprudência). A Torah é o elemento nuclear, o original, o inesgotável, aquele círculo que, tendo infinitos lados, possibilita, igualmente, infinitos

\footnotetext{
${ }^{4}$ Segundo Benjamin, "Nas línguas particulares, incompletas portanto, o que significam nunca se encontra em relativa independência, como nas palavras ou frases consideradas isoladamente, senão que em constante, na expectativa de emergir como a língua pura da harmonia de todos estes modos de significar". A Tarefa do Tradutor. P. 12.
} 
comentários, infinitas interpretações, o que, a rigor, não é senão infinitas traduções. A enorme diferença, no entanto, é que Benjamin não aplica essa forma de escrita no sentido de instalar uma tradição hermenêutica, sob o risco de sucumbir ao historicismo. Ainda que os pressupostos hermenêuticos da teologia judaica exijam do bom exegeta o retorno ao núcleo original (Torah), ele (o intérprete) o faz, por vezes, pela mediação da autoridade rabínica que constitui o Talmud. Original e Torah demandam traduções porque são a fonte primeira e sob tal estatuto preservam (velam) uma dimensão intraduzível. É, pois, a inesgotabilidade própria do original que engendra historicamente a sobrevida. $\mathrm{O}$ original sobrevive, assim, na tradução. Quanto mais tradução, mais sobrevida; quanto mais sobrevida, mais tradução quanto mais imanência, mais transcendência, e vice-versa.

\section{CONSIDERAÇÕES FINAIS}

À guisa de conclusão podemos dizer que à Literatura Comparada torna-se imprescindível a tessitura teórica engendrada a partir de Borges e Benjamin. Daí se infere que o ato de traduzir não reverbera um lugar subalterno. Ao contrário, a tradução enquanto vida do original inverte o estatuto da relação entre metrópole e nações pós-colonialistas. Quer dizer que aquela dimensão gnosiológica que se atualiza ato de traduzir só é possível no câmbio de uma língua a outra e que quem traduz tem o primado desse conhecimento.

No entanto, vale esclarecer que o principal elemento, extraído dos textos de Borges - a máxima de que quanto mais tradução mais conhecimento se tem do original - não trata de afirmar apenas um critério quantitativo sem nenhum pudor, como se toda e qualquer tradução ou interpretação valessem. Para Borges o limite é a obra. Dentro dos limites da obra, pois, ele afirma que a riqueza das traduções pode comportar diversidade tanto quanto contradições, o que só potencializa o conhecimento acerca do original. É por isso que o original se mostra em inúmeras faces engendrando a sobrevida da obra em suas traduções.

Trata-se do espaço de interseção que transcreve a aproximação entre a teoria do rascunho de Borges e a noção de sobrevida extraída de Benjamin. Nesse sentido, a primeira conferência de Borges em Harvard explicita a possibilidade dessa aproximação vista por nós: "Um livro é um objeto físico num mundo de objetos físicos. É um conjunto de símbolos mortos. E então aparece o leitor certo, e as palavras - ou antes, a poesia por trás das palavras são meros símbolos - saltam para a vida, e temos a ressurreição da palavra". (BORGES, 2007, p. 70). A ressurreição da palavra corresponderia, assim, à sobrevida do original. 
Segundo Benjamin (1994, p. 7), “a tradução mantém um vínculo estreito com o original [...] vínculo de vida". Por outro lado, inferimos de As versões homéricas de Borges o princípio de que "quanto mais traduções, mais conhecimento se tem do original". Esse princípio também está de acordo com a idéia benjaminiana de sobrevida: "Nelas [traduções] a vida do original, em renovação constante, alcança um outro e mais extenso desdobramento. Tal desdobramento é, como o de uma vida originária e de nível elevado, determinada por uma finalidade também originária e superior”. (BORGES, 1999, p. 8).

Para Borges o tratamento dado ao original e à tradução deve ser igualitário. Na quarta conferência proferida em Harvard, ele diz (BORGES, 2007, p. 71):

\begin{abstract}
[...] a diferença entre uma tradução e o original não é a diferença dos próprios textos. Suponho que se não soubéssemos qual era o original e qual era a tradução, poderíamos julgá-los com equidade. Mas infelizmente não podemos. E assim, a obra do tradutor sempre é tida como inferior - ou, o que é pior, é sentida como inferior ainda que, verbalmente, a versão seja tão boa quanto o texto.
\end{abstract}

A isonomia entre original e tradução, corroborada por Borges em Pierre Menard, autor de Quixote, denuncia a superstição acerca da inferioridade da tradução. Surge, assim, a possibilidade de lançar mão da análise comparativa de traduções como um estudo de Literatura Comparada, sem o peso de seu um trabalho menor e que ser auditado sempre pela ideia de original.

As traduções, então, não devem ser postas sob um lugar de inferioridade em relação ao original. Ao contrário, a tradução, ainda que literal, não é fiel, sugere Borges. Na quarta conferência proferida em Harvard, intitulada Música da Palavra e Tradução, ele diz (2007, p. 72): "No século XIX, um mestre de grego bastante esquecido, Newman, ensaiou uma tradução literal de Homero em hexâmetro. Era seu propósito publicar uma tradução 'contra' o Homero de Pope". Não estamos sugerindo, no entanto, que Borges despreze a tradução literal, até porque seria uma contradição em relação ao texto Pierre Menard, autor de Quixote. O que ele perece enfatizar é que, a despeito de, muitas vezes, a tradução literal comportar inigualável beleza, ela jamais atingiria o original, o que mais uma vez possibilita a articulação com Benjamin.

$\mathrm{Na}$ quinta conferência proferida em Harvard, intitulada "O credo de um poeta", o poeta sugere, ao explicar o processo da produção da tessitura de $O$ imortal, que escrever é atualizar o atual. Inferimos, assim, que a tradução, enquanto atualização do original se faz original, na medida em que é sua sobrevida. Ela - a tradução - leva em consideração a intenção de significar própria de cada língua, como diz Benjamin: “Assim, a tradução tem por 
fï exprimir (zweckmässig) exprimir a relação mais íntima entre as línguas. A tradução manifestar e restituir esta relação oculta; pode, contudo, apresentá-la [...] Na verdade é esta apresentação de um significado [...] (BENJAMIM, 1994, p. 9). O nexo entre Borges e Benjamin parece, pois, evidente aqui mais uma vez.

Finalmente, o elogio da tradução consiste em atribuir-lhe valor à medida que ela é tomada como a expressão multifacetada do original. Não se trata, portanto, de valorizar a tradução em função da proximidade do original. A noção de tradução que tem sido compreendida sob um lugar de inferioridade é, então, rejeitada. Nesse sentido, a compreensão da tradução sob o domínio da herança platônica - a tradução possui valor de cópia, portanto, um lugar subalterno em relação ao original -, a qual exigiria de quem traduz e de quem recebe a tradução a fidelidade ao original, é recusada. Diz o poeta (BORGES, 1999, p. 118): "Momento talvez chegue em que tomará a tradução de Homero feita por Pope não apenas como uma bela obra de arte (de fato é,), mas como fiel ao original”. A valorização da língua para a qual se traduz, a valorização do tradutor e a valorização da tradução parecem possuir um peso relevante para Literatura Comparada. A relevância consiste em sugerir uma atitude não canônica, expressão do labor das teorias críticas da Literatura Comparada na América Latina.

\section{REFERENCIAS}

APPADURAO, Arjun. Disjunção e diferença na economia cultural global. In: Cultura global. Nacionalismo, globalização e modernidade. Petrópolis: Vozes, 1999.

BENJAMIN, W. A tarefa do tradutor. In: Cadernos do mestrado/licenciatura. Rio de Janeiro: UERJ, 1994.

BENJAMIN, W. Magia e técnica, arte e política. São Paulo: Brasiliense, 1994.

BORGES, J. L. As versões homéricas. In: Obras completas. Vol. I-IV. Barcelona: Emecé, 1999.

D’ANGELO, Biagio. Borges en el centro del infinito. Lima: UNMSM, 2005.

PASTORMERLO, Sérgio. Borges y la traducción. In: Borges studies on line. J. L. Borges Center for St. \& Documentation. Internet: 20/04/2009.

(HTTP://www.hum.au.dk/romansk/borges/bsol/pastorm1.htm).

PINASCO, Olga. Los escandinavos aman a Borges. Claudia, nº 292, Buenos Aires, outubro de 1981, p. 117-119.

YÚDICE, George. A conveniência da cultura. Usos da cultura na era global. Trad. MarieAnne Kremer. Belo Horizonte: UFMG, 2006. 